Western North American Naturalist 71(1), (C) 2011, pp. 86-96

\title{
UNGULATE HERBIVORY ON ALPINE WILLOW IN THE SANGRE DE CRISTO MOUNTAINS OF COLORADO
}

\author{
Linda C. Zeigenfuss ${ }^{1,3}$, Kathryn A. Schoenecker ${ }^{1}$, and Lisa K. Van Amburg2
}

ABSTRACT.-In many areas of the Rocky Mountains, elk (Cervus elaphus) migrate from low-elevation mountain valleys during spring to high-elevation subalpine and alpine areas for the summer. Research has focused on the impacts of elk herbivory on winter-range plant communities, particularly on woody species such as willow and aspen; however, little information is available on the effects of elk herbivory on alpine willows. In the Sangre de Cristo Mountains of south central Colorado, select alpine areas appear to receive high levels of summer elk herbivory, while other areas are nearly unbrowsed. In 2005 and 2008, we measured willow height, cover, and utilization on sites that appeared to be used heavily by elk, as well as on sites that appeared to be used lightly, to determine differences between these communities over time. We found less willow cover and shorter willows at sites that received higher levels of browsing compared to those that had lower levels of browsing. Human recreational use was greater at lightly browsed sites than at highly browsed sites. From 2005 to 2008, willow utilization declined, and willow cover and height increased at sites with heavy browsing, likely owing to ownership change of adjacent valley land which led to (1) removal of grazing competition from cattle at valley locations and (2) increased human use in alpine areas, which displaced elk. We discuss the implications of increased human use and climate change on elk use of these alpine habitats.

Resumen.-En muchas áreas de las Montañas Rocosas, el ciervo rojo (Cervus elaphus) migra durante la primavera de valles montañosos de baja elevación a áreas altas subalpinas y alpinas para el verano. Hasta ahora la investigación se ha enfocado en el impacto de la herbivoría del ciervo rojo sobre las comunidades de plantas en el invierno, particularmente en las especies leñosas como el sauce y el álamo; sin embargo, existe poca información disponible sobre el efecto de la herbivoría del ciervo rojo en los sauces alpinos. En la cordillera Sangre de Cristo al centro-sur de Colorado, ciertas áreas alpinas parecen tener altos niveles de herbivoría de verano por el ciervo rojo, en tanto que otras áreas quedan casi sin ramoneo. En 2005 y 2008 medimos la altura, cobertura y uso de los sauces en sitios en los que parecía haber sido abundante el ramoneo y los comparamos con sitios donde parecía haber sido más ligero, a fin de determinar las diferencias entre estas comunidades en el tiempo. Encontramos menos cobertura y altura de sauces en los sitios que recibían niveles más altos de ramoneo en comparación a los que tenían menos evidencia de ello. El uso humano recreativo era mayor en los sitios de ramoneo ligero que en donde era abundante. De 2005 a 2008, disminuyó el uso y aumentó la cobertura y la altura en sitios de ramoneo abundante, probablemente debido a que un valle adyacente cambió de propietario, lo cual provocó (1) la eliminación de la competencia por el pastoreo en ganado en el valle; y (2) un aumento del uso humano en áreas alpinas, desplazando al ciervo rojo. Discutimos las implicaciones del aumento del uso humano y el cambio climático en el uso por el ciervo rojo de estos hábitats alpinos.

In many locations throughout the Rocky Mountains, elk (Cervus elaphus) migrate each spring from low-elevation montane valleys to high-elevation summer ranges in subalpine forests and alpine tundra, then return to low elevations in autumn (Brazda 1953, Adams 1982). Historically, resource managers and researchers have considered winter range to be limiting to ungulates, and thus much attention has been devoted to the effects of elk on winter-range vegetation, particularly willows (Salix spp.), quaking aspen (Populus tremuloides), and upland shrub habitats (Singer et al. 1994, White et al. 1998, Zeigenfuss et al. 2002, Johnston et al. 2007, 2008). In some places, elk have become concentrated on their winter ranges in the Rocky Mountain West. However, very little research has been done on the effects of elk concentrations on alpine summer ranges. Effects of intense browsing by elk on alpine willows have been observed in Rocky Mountain National Park, Colorado (Zeigenfuss 2006), but little data has been collected to quantify long-term impacts of intense ungulate herbivory in these sensitive range systems.

Seasonal migratory movements of elk, as well as elk distribution within seasonal ranges, can be influenced by many factors. Seasonal migrations may be instigated by a desire to follow the greenup of nutritious forages to higher elevations where animals can also escape summer heat and

${ }^{1}$ U.S. Geological Survey, Fort Collins Science Center, 2150 Centre Ave Building C, Fort Collins, CO 80526

${ }^{2}$ Saguache District, Rio Grande National Forest, 46525 State Hwy. 114, Saguache, CO 81149

3E-mail: linda_zeigenfuss@usgs.gov 


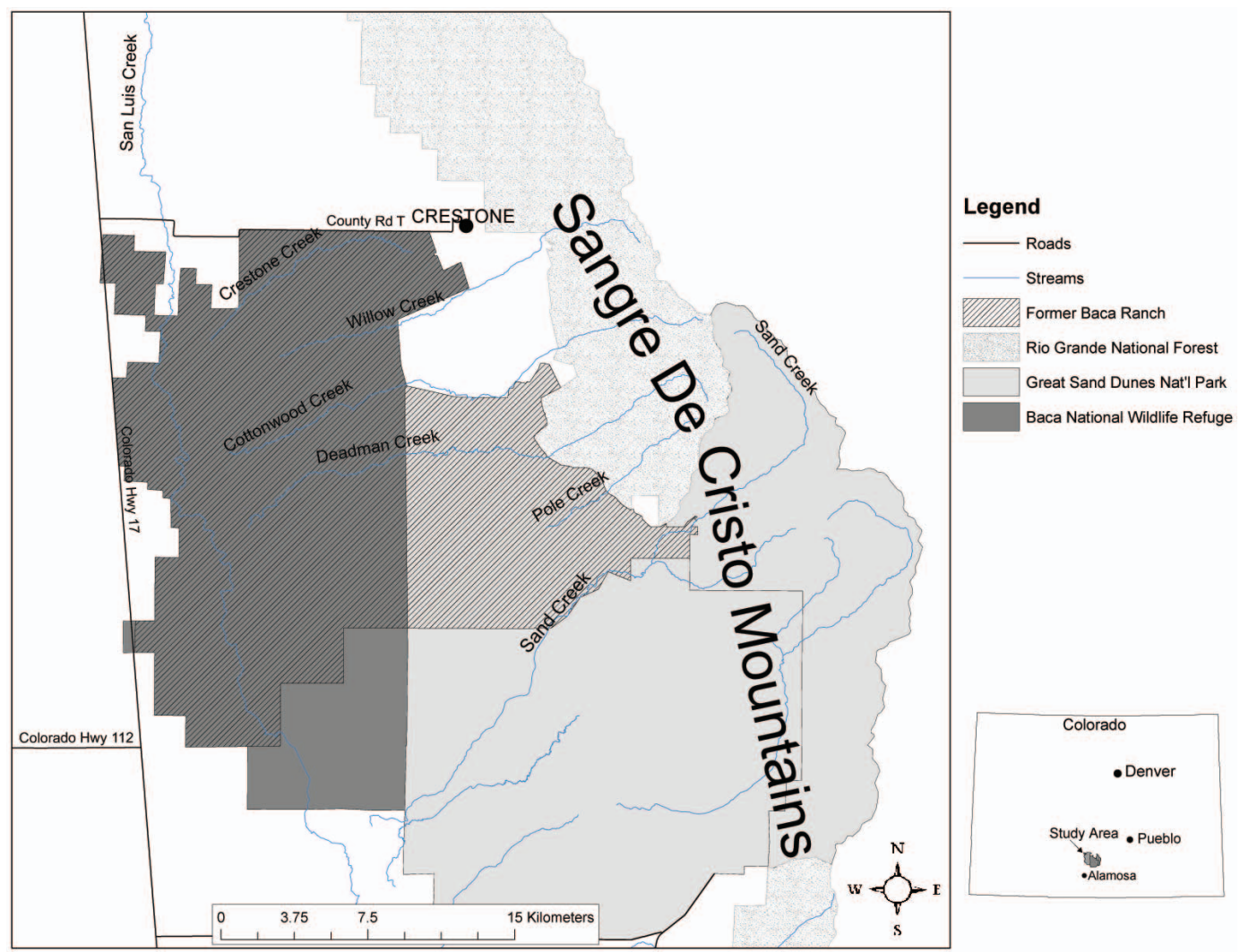

Fig. 1. Area used by the south central San Luis Valley, Colorado, elk herd.

insects (Brazda 1953, Hebblewhite et al. 2008, Hebblewhite and Merrill 2009). Other factors which may influence seasonal elk movements include livestock grazing and human disturbances (e.g., hunting, seasonal road use, and other forms of seasonal recreation; Rowland et al. 2000, Coe et al. 2001, Stewart et al. 2002, Naylor et al. 2009, White et al. 2009).

In south central Colorado, a portion of the elk herd that winters on the east side of the San Luis Valley are found annually, from March to November, in the Rio Grande National Forest (RGNF), the Baca National Wildlife Refuge (BNWR), The Nature Conservancy's Medano-Zapata Ranch, Great Sand Dunes National Park and Preserve (GSDNPP), and adjoining private lands (Fig. 1; K. Schoenecker, U.S. Geological Survey, unpublished data; R. Rivale, Colorado Division of Wildlife [CDOW], personal communication). Some elk in this herd migrate to and summer in areas near and above timberline of the Sangre de Cristo Mountains (Fig. 1); however, a portion of this herd summers on the valley floor, indicating that factors of heat and insects do not necessarily drive seasonal movements (K. Schoenecker unpublished data).

Prior to 2005, the lands that now make up the BNWR and the adjacent GSDNPP lands to the east were managed as a private ranch-the Baca Ranch. During the decade immediately prior to the transfer of the ranch lands to federal land-management agencies in late 2004, approximately $6500-8000$ yearling steers and approximately $2500 \mathrm{cow} / \mathrm{calf}$ pairs were seasonally grazed and rotated through the 92,500 acres of the ranch each spring through summer (R. Garcia, U.S. Fish and Wildlife Service, personal communication). During this time, wildlife managers from the Colorado Division of Wildlife observed more intense willow browsing by ungulates in the adjacent alpine areas of the Deadman Creek and Pole Creek drainages compared to browsing in other nearby alpine areas. These creeks extended from the Baca Ranch onto the adjoining Rio Grande National Forest. But most other nearby alpine areas on the Rio Grande 
National Forest appeared to receive lower levels of elk herbivory. Public access to the alpine areas to the north, south, and east of Deadman and Pole creeks was available from trailheads on RGNF and GSDNPP lands, but trail access to these 2 drainages was limited by private ownership of the access points of forest trails and by sheer cliffs, which prevented access from over the crest of the mountains. As a result, human disturbance in the alpine areas of the Deadman and Pole Creek drainages was very limited compared to neighboring areas, which received much use by backpackers, climbers, and other backcountry recreationists.

Managers speculated that high densities of cattle and related ranching activities encouraged elk movement up the Deadman and Pole Creek drainages to the alpine areas, and that these areas were particularly favored because they experienced low recreational use. However, no quantitative data on willow decline or browsing levels existed to compare these areas with other nearby alpine areas. The objectives of our study were to (1) quantify the extent of ungulate browsing in alpine willow communities, (2) collect baseline data for future measurements of trends in willow cover and height, and (3) quantify summer browse intensity at high-elevation areas used by the eastern San Luis Valley elk herd, including areas perceived to be subject to high and low levels of elk use.

Currently, GSDNPP is beginning the process of creating an elk management plan. Information on the effects of elk herbivory, and potentially other ungulate herbivory, on alpine willow communities is important to properly identify the effects of management actions on all vegetation communities in GSDNPP. In particular, alpine vegetation communities may become subject to increased environmental stress if future climate change leads to warmer and/or drier conditions. Management actions that affect ungulate distributions need to consider the combined effects of climate-induced as well as herbivory-induced dynamics in these habitats.

\section{Study Area}

The study area was located in the Sangre de Cristo Mountains on the eastern side of the San Luis Valley of south central Colorado (Figs. 1, 2). The Cottonwood Creek, Deadman Creek, and Pole Creek study sites are managed by the Saguache District of the U.S. Forest Service (USFS),
Rio Grande National Forest. The Upper Sand Creek Lake and Little Sand Creek Lake sites are within GSDNPP and managed by the National Park Service (NPS). The study sites range from $3555 \mathrm{~m}$ to $3765 \mathrm{~m}$ elevation. Sites were located in stands of dwarf alpine willows (primarily Salix brachycarpa, Salix wolfii, and Salix planifolia). Prior to 2005, the alpine areas around Deadman Lakes were virtually inaccessible to the general public, as the land at the base of the Deadman Creek drainage leading to the lakes was under private ownership, with only a few hunting groups allowed access to the backcountry trails each year. The top of the drainage is not easily accessible by routes over the tops of the ridgelines. In fall 2004, the land was acquired by the federal government and management transferred to the U.S. Fish and Wildlife Service, the NPS, and the USFS. Although motorized access to the trails at the base of the drainage remains closed to the public, access by horse and on foot is permitted. As a result, public use of the Deadman drainage has increased from a few small groups per year to 5-10 campers per week during the summer and fall (Ron Rivale, CDOW, personal communication). The adjacent valley floor was grazed by domestic cattle for several decades prior to the change in management (federal agencies) in 2005. The Pole Creek drainage has a similar history to that of Deadman Creek.

Cottonwood and Upper Sand Creek lakes are both located in areas that are near trails with good public access and that are used heavily by hikers, backpackers, fishermen, and climbers. The area around Cottonwood Lake is used as a staging area for climbers attempting to scale the popular Crestone Needle and Crestone Peak. Upper Sand Creek Lake is a popular destination for recreationists as well, but Little Sand Creek Lake receives much less human visitation (Fred Bunch, NPS, personal communication), likely because of its inaccessibility and distance from trailheads $(15 \mathrm{~km})$.

\section{METHODS}

In September 2005, we initiated a survey of alpine willow in the Deadman Creek drainage (hereafter Deadman) of the Rio Grande National Forest. We selected the alpine willow areas around Cottonwood Lake and Cottonwood Creek (hereafter Cottonwood) as a presumably less heavily browsed comparison to Deadman (Fig. 2). 


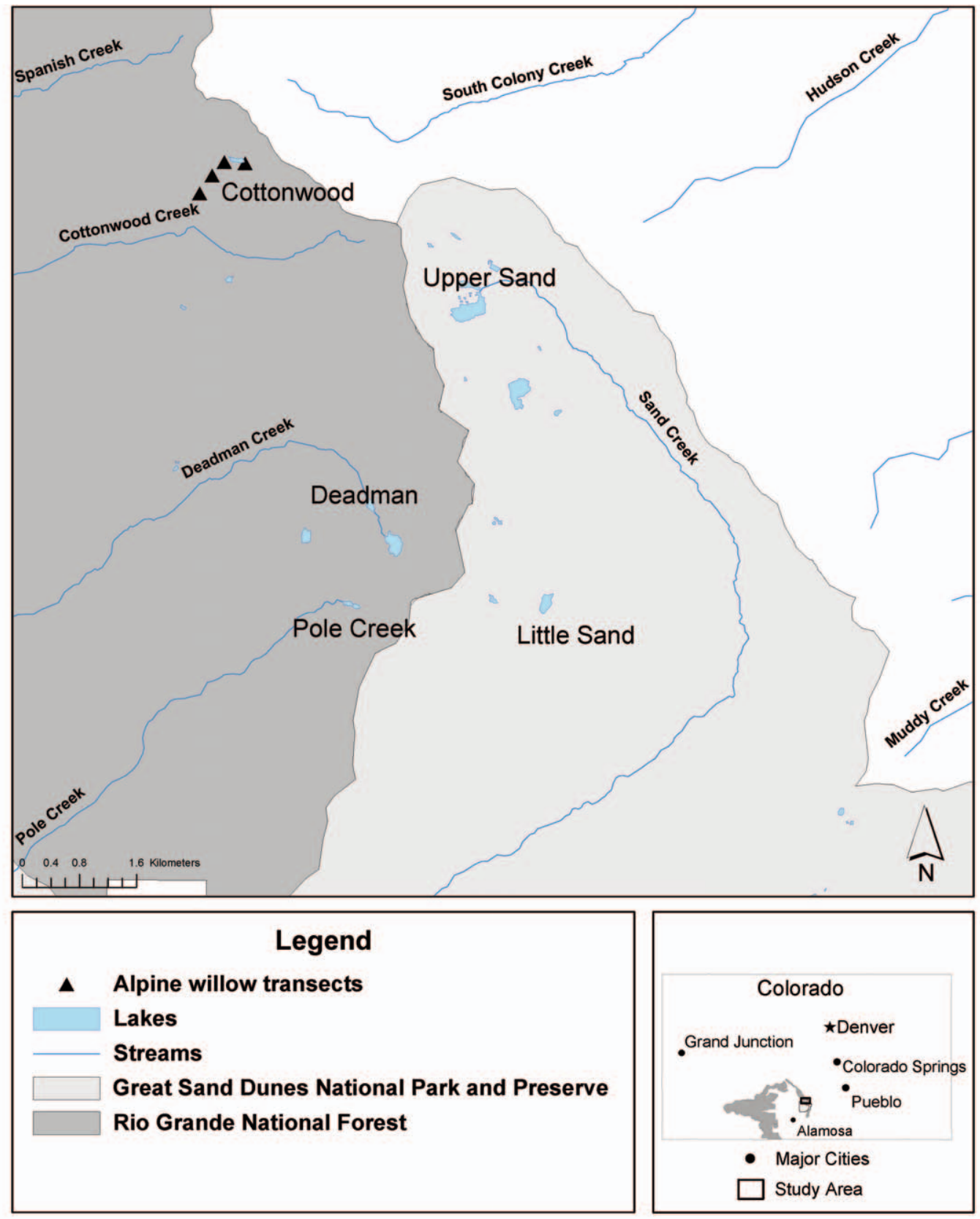

Fig. 2. Alpine willow study site locations on the Rio Grande National Forest and Great Sand Dunes National Park and Preserve in the Sangre de Cristo Mountains of Colorado. Inset shows the location of the study area within Colorado.

Several 30-m transect lines were established at each site. We determined the number of transect lines based on the relative size of the alpine willow areas, distributing more to Deadman (9 transects), where there were several lakes and stream branches above timberline, than to Cottonwood
(4 transects), where there was a single lake and stream (Table 1).

In August 2007, USFS biologists established ungulate pellet plots at Deadman and measured them in 2007 and 2008 to further quantify ungulate presence in this drainage. 
In 2008, we added 5 transects at Pole Creek, 4 transects at Upper Sand Creek Lake (hereafter Upper Sand), and 1 transect at Little Sand Creek Lake (hereafter Little Sand; Fig. 2) in order to expand our inference beyond 2 study sites. However, because of inclement weather, we were only able to measure height and cover at one transect at Little Sand. All sites were sampled during a 2-week period in late August/ early September during each sampling year (Table 1).

During all sample years, willow cover, percent of plant canopy that was dead, willow height, and browse intensity (percent of shoots browsed) were measured using a line-intercept method (Canfield 1941) along 30-m transect lines. Transect lines were laid out along a random bearing through willow patches; willow patches were selected for sampling based on presence of a large enough patch to contain a 30-m transect line. If the initial random compass bearing led in a direction that exited the willow patch before the 30-m distance was reached, the back bearing and then alternate random bearings were attempted until one that led through the willow patch was found. UTM coordinates of each transect line were recorded using a handheld GPS (Garmin, Ocean Isle Beach, NC). Lines began at the edge of a willow patch to ensure that any heavier levels of browsing occurring near patch edges were included. At any point where the line intercepted the canopy of a willow, the length of that intercept was recorded, along with the average height and species of the willow. For each willow that intercepted the transect line, the number of browsed and unbrowsed current year's annual growth (CAG) shoots on the plant were also measured. Where willow clumps were continuous, thus making it difficult to distinguish individual plants, or where the growth consisted of many single shoots emerging from the ground, a $0.5 \times 0.5-\mathrm{m}$ plot was used for counting browsed and unbrowsed shoots instead of counting on the entire plant or clump.

To measure elk and other ungulate presence, eight $25-\mathrm{m}^{2}(5 \times 5-\mathrm{m})$ fecal plots were established at Deadman in 2007 and remeasured in 2008 in order to index species and density of ungulate use. The center of each plot was located with a handheld GPS and the corners marked with landscape staples. The number of fecal piles and ungulate species, and whether the fecal pile appeared to be fresh or old 


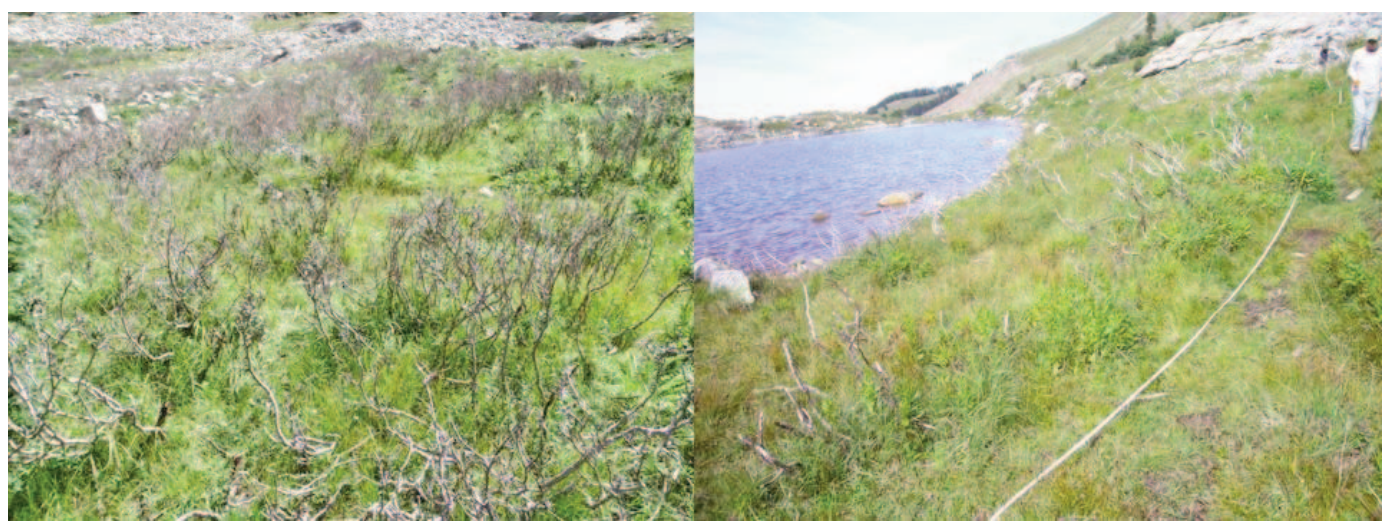

Fig. 3. Typical willow transects measured near Deadman Lakes (left) and Pole Creek Lake (right), Rio Grande National Forest, Colorado, 2008.

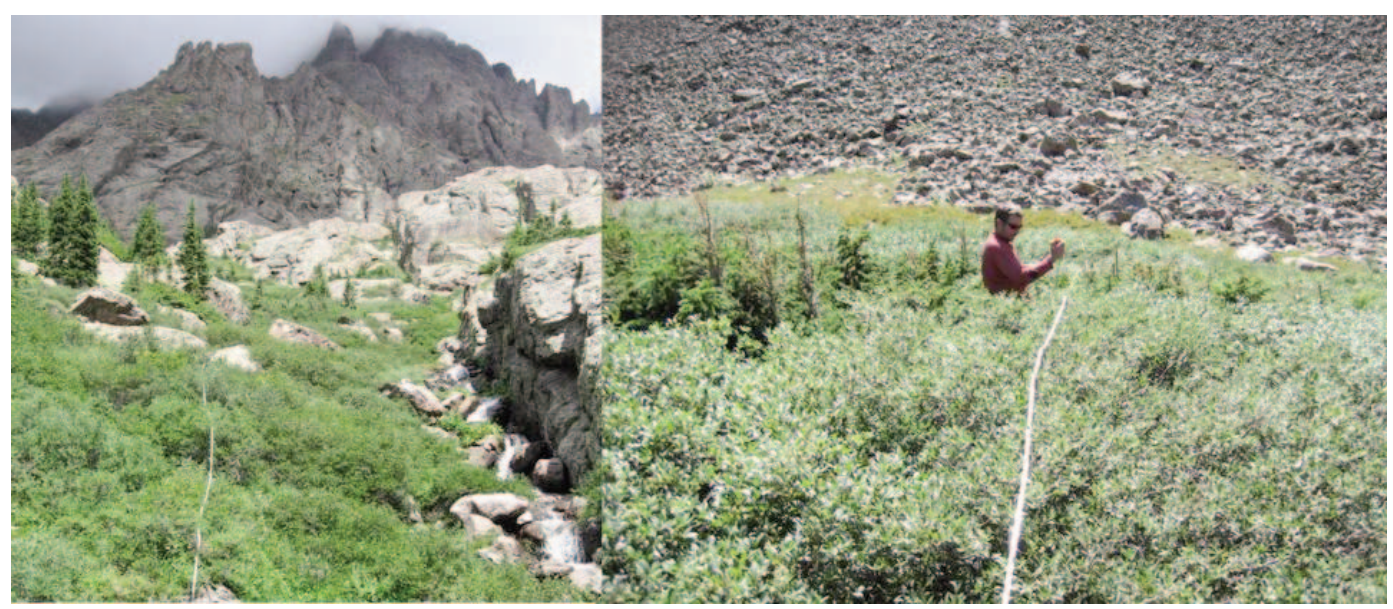

Fig. 4. Typical willow transects measured near Cottonwood Lake (left), Rio Grande National Forest, and Upper Sand Creek Lake (right), Great Sand Dunes National Park and Preserve, Colorado, 2008.

(weathered and dried out) was recorded, and then the plot was cleared for remeasurement in 2008. A fecal "pile" was defined as 5 or more individual pellets that were either in a pile or strewn about in a line (or even more scattered in appearance). In 2005, only general visual observations were made as to amount and species of ungulate scat along the willow transect lines.

Statistical analyses were performed using SAS statistical software, version 9.1. We used nonparametric tests to evaluate differences between 2005 and 2008 measures for each site and a Kruskal-Wallis test statistic to determine significance at the 0.05 level. Measured variables were compared between all sites for 2008 and between the Deadman and Cottonwood sites in 2005 by using general linear models and Tukey's studentized range tests for multiple mean comparisons to determine significant differences at the 0.05 level.

\section{Results}

The Deadman and Pole Creek sites appeared to be affected more heavily by ungulate herbivory than the Cottonwood and Upper Sand sites (Figs. 3, 4). Willows at Cottonwood, Upper Sand, and Little Sand had high percentages of live canopy and were characterized by dense, intertwined plant canopies with low levels of browsing evidence. These sites had willow cover measures of $>50 \%$, with much less dead canopy 

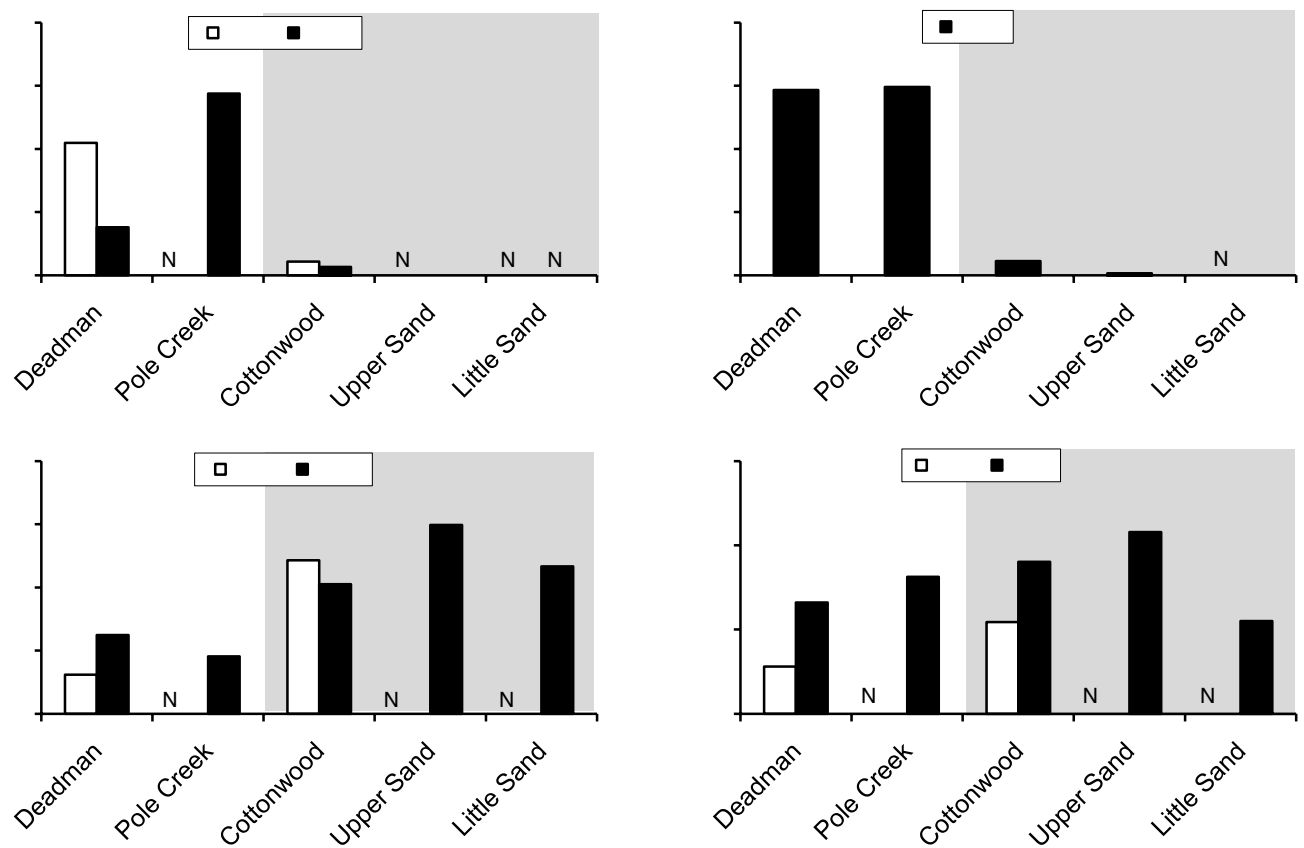

Fig. 5. (a) Average willow percentage of browsed shoots; (b) percent dead canopy; (c) percent willow cover; and (d) height in centimeters at alpine willow sites on the Rio Grande National Forest and Great Sand Dunes National Park and Preserve in the Sangre de Cristo Mountains of Colorado. Gray background shading indicates that the area receives high human use.

$(<5 \%)$ than the Deadman and Pole Creek sites. Willow canopies at Deadman and Pole Creek had a higher percentage of browsed shoots and larger amounts of dead material than willows at Cottonwood, Upper Sand, and Little Sand. Browse intensity, as measured by the percentage of shoots browsed (\% leader use), was higher at Pole Creek than at any other sites $(P<0.0001)$ in 2008 and was higher at Deadman than at Cottonwood and Upper Sand (Fig. 5a). Percent of dead willow canopy was greater $(P<0.001)$ on all the Deadman and Pole Creek sites compared to the Cottonwood and Upper Sand sites (Fig. 3, 4, 5b). Willow cover was significantly lower $(P=0.002)$ at Deadman and Pole Creek compared to Cottonwood and Upper Sand (Fig. 5c) in 2008. Willow heights were not substantially different among sites (Fig. 5d).

In 2005, average willow cover was approximately 4 times greater at Cottonwood, where only a minimal amount of ungulate sign was observed, compared to Deadman (Fig. 5c). Willow heights were also greater at Cottonwood than at Deadman (Fig. 5d) in 2005. Percentage of browsed shoots was about $5 \%$ on willows at
Cottonwood but averaged over $50 \%$ at Deadman (Fig. 5a) in 2005. However, in 2008, percentage of browsed shoots dropped by more than half at Deadman $(P=0.005$, Fig. 5a) and cover was twice as great at Deadman in 2008 compared to $2005(P=0.009$, Fig. 5c). Average willow height more than doubled from 2005 to $2008(P=$ 0.003 ) at Deadman. Between 2005 and 2008, percentage of browsed shoots and cover declined slightly $(P>0.05)$ at Cottonwood, and average willow height increased $67 \%$; however, this increase was not significant $(P=0.39$, Fig. 5d).

Fresh scat and tracks of bighorn sheep (Ovis canadensis) or mule deer (Odocoileus hemionus) were observed at Deadman in 2005 . No bighorn or mule deer scat was found on the pellet plots in 2007 , but $0.4(\mathrm{SE}=0.2)$ bighorn or mule deer pellet groups per plot were observed in 2008. Bighorn or mule deer sign was observed along 1 of 4 willow transect lines around Cottonwood in 2005 and in the vicinity of Cottonwood in 2008.

Both elk tracks and fresh elk scat were observed at Deadman in 2005. An average of 8.1 
$(\mathrm{SE}=1.2)$ fresh elk pellet groups per plot $(0.32$ groups $\cdot \mathrm{m}^{-2}$ ) were observed at Deadman in 2007, but that number dropped to $1.9(\mathrm{SE}=0.9$; 0.08 groups $\cdot \mathrm{m}^{-2}$ ) in 2008 . Elk sign was not observed in either year at Cottonwood.

\section{Discussion}

Alpine willow sites in the central Sangre de Cristo Mountains displayed a range of conditions and levels of ungulate use that varied between sites and years. Areas that were subject to higher levels of ungulate use, as determined by pellet plots and browse levels, had willows that were shorter in stature, a greater percentage of dead canopy, and overall less willow cover than areas with little or no ungulate use. Fecal-pellet data indicated that elk are the primary ungulate present in these drainages during summer.

The level of elk use in the alpine areas we studied was apparently influenced by recreational use and by competitive displacement by cattle at lower elevations. In areas where cattle activity was concentrated on the valley floor during the summer, elk apparently moved up to higher elevations in the drainages that were used most heavily by cattle at lower elevations. Coe et al. (2001) found that elk in northeastern Oregon decreased their use of pasture and forest areas during summer when cattle were present. In the same region, elk also used lower elevations when cattle were absent but moved to higher elevation when cattle were present (Stewart et al. 2002). While there are several creeks which cross the former Baca Ranch (Cottonwood, Willow, Crestone, Sand, Deadman, and Pole; Fig. 1), only Deadman and Pole creeks went directly from the most heavily ranched areas to the public lands, possibly funneling elk from the ranchlands in spring and summer to these alpine areas.

Human development (housing and roads) may also have influenced the distribution of elk into these 2 drainages. Roads and disturbance associated with roads have been shown to influence seasonal and landscape distribution of elk (Lyon 1979, Cole et al. 1997, Rowland et al. 2000). All the other creeks, except for Sand Creek, passed from public lands through residential area before entering the Baca Ranch lands, so elk would have to cross through the town of Crestone or an adjoining subdivision to migrate to higher elevations. They may have avoided these residential areas by migrating along the Deadman and Pole Creek drainages.

Finally, recreational use in alpine areas may have influenced the degree to which elk used these alpine ranges. Elk would be able to travel between the various drainages at lower elevations on National Forest land, though topography likely limits their crossing over the top of many peaks because of sheer cliffs. However, elk browsing of willows in the upper Sand Creek and Cottonwood Creek drainages was much lower than at Pole Creek and Deadman. We believe recreational use by hikers, backpackers, and climbers inclined elk to avoid the prior 2 drainages. Sand Creek Lakes is a popular destination for backcountry campers in GSDNPP, and Cottonwood Lake is a popular camping spot for climbers attempting to scale nearby Crestone Peak and Crestone Needle (F. Bunch, NPS, personal communication; S. Neid, U.S. Geological Survey, personal observation). Trails and human foot traffic have been found to influence elk movements in other studies. Elk avoided areas $<600 \mathrm{~m}$ from hiking trails in the Black Hills of South Dakota (Millspaugh 1999). Elk often move in response to approach by hikers or persons on foot (Schultz and Bailey 1974, Naylor et al. 2009), but these effects are usually shortlived and do not affect animal distribution. We believe that the longer duration of a backcountry camping visit compared to hiking, however, may cause enough disturbance to displace elk for longer time periods, depending on the number of campers and frequency of camper presence.

Willow in our study areas recovered with decreased browse pressure. In the time between 2005 and 2008, substantial changes to the management of lands adjacent to the alpine range, and an increase in public access to alpine areas, resulted in fewer elk concentrating in the Deadman and Pole Creek drainages, based on pellet plots and less ungulate use of the alpine areas at the tops of these drainages. Although these drainages are still receiving more elk browsing than the Cottonwood and Sand Creek drainages, the decrease in browse pressure is resulting in increases in height and cover of willows observed in 2008. This change in elk use (and presumably elk distribution) may have been caused by increased human activity in the Deadman and Pole Creek drainages, the removal of cattle from the valley adjacent to the drainages (which decreased forage competition with cattle that may have previously pushed elk to seek forage 
and shade at higher elevations), or a combination of these factors. With greater human use of the area, and increased availability of forage on the valley floor, elk use appears to have declined in Deadman and Pole Creek drainages (R. Rivale, CDOW, personal communication). Continued monitoring of these areas is necessary, however, to determine whether these trends in elk use are just a short-term phenomenon that might be due to other factors such as recent weather trends, or to changes in overall elk distribution in the adjacent San Luis Valley because of management actions taken by land management agencies.

It is possible that precipitation during 20062008 influenced willow growth. There are no high-elevation weather stations located near the study area; however, 2 NOAA COOP stations are located within 15-25 km (Crestone and Great Sand Dunes) at lower elevations (>1000 m lower). An examination of the available precipitation data from 2006-2008 found that annual precipitation was higher than the 25-year average at both stations. Much of this area experienced drought in the early part of this decade, and the winter of 2005-2006 had extremely low snowpack in these mountains (L. Zeigenfuss personal observation). These conditions should have affected all study sites similarly. Any decline in willow cover or increase in dead canopy attributable to drought, or subsequent willow growth due to abundant precipitation, should have been evident at all sites. Therefore, the change in levels of elk herbivory at these sites is likely the primary factor in the differences between sites and measurement periods.

Whatever the cause of variation in elk use of alpine willows observed in this study, we can still conclude that high levels of elk browsing in these delicate systems leads to increased percentage of dead willow canopies and suppressed heights of alpine willows. Studies of the effect of elk browsing in both summer and winter in montane and subalpine riparian habitats indicate that intense browsing can lead to declines in willow cover and death of individual willows, and can compound the effects of poor hydrologic conditions upon willow growth and survival (Peinetti et al. 2001, 2002, Zeigenfuss et al. 2002, Johnston et al. 2007). In alpine environments, soils are nutrient poor and the effects of chronic herbivory can reduce plant fitness and lead to increased mortality (Chapin 1980). Deciduous species, such as alpine willows, are able to rapidly translocate nutrients into new growth early in the growing season, making the willows particularly susceptible to herbivory at this time (Chapin 1980). In addition, shortened growing seasons in alpine regions allow little time for leaf regrowth and replacement of the energy investment lost to herbivory before the end of the growing season (Archer and Tieszen 1980).

As federal land managers consider future access to remote drainages, they should consider the effects of management decisions on ungulate populations that use these remote areas and how management actions may influence future elk distributions in alpine areas. An awareness of the potential vulnerability of alpine systems to climate-induced changes and how that may impact their ability to sustain high levels of herbivory is particularly important. Information gained through observation of the effects of seasonal ungulate use of alpine plants may be valuable to future management if Rocky Mountain alpine regions experience shifts in ungulate distribution, density, and/or grazing seasons.

Some climate projection models indicate a warming climate in future decades for this region of Colorado (Ray et al. 2008). If warming of subalpine and alpine regions occurs, seasonal ungulate use of alpine areas may be extended or even begin to occur year-round as large ungulates, such as elk, move upward in elevation to escape heat at lower elevations and to take advantage of alpine food sources that may be increasingly available because of earlier snowmelt in spring and later snowfall in autumn. Early snowmelt could increase accessibility to alpine willow stands earlier in the growing season when willow are nutritionally advantageous forage for elk (Morgantini and Hudson 1989). If fall snows arrive later, elk could also remain on high-elevation ranges later in the year, diminishing the plant material that could contribute to the plants' nutrient reserves for the following year. Lower snowpacks may leave parts of shrubs uncovered during the coldest, windiest parts of winter and subject them to frost kill and desiccation. A short-term drought could potentially decrease water availability to alpine shrubs for several years. Any of these stresses may lead to willows that are unable to withstand increased levels of herbivory by elk and other ungulates.

Monitoring elk distributions and/or alpine willow and herbaceous vegetation condition is necessary in order to detect substantial change in these variables if managers wish to adaptively manage wildlife and vegetation to ensure their 
persistence. However, if sudden shifts in elk distribution lead to increased use of alpine summer ranges for extended periods of time (i.e., several consecutive years), research results may not become available within a time frame that would allow initiation of management actions that could prevent damage to sensitive alpine ranges in this part of the Sangre de Cristo Mountains.

If land managers wish to fully understand the influence of recreational and livestock use on elk distributions and herbivory in alpine ecosystems, then further studies are needed that document the spatial and temporal extent of recreational and livestock use and the movements of elk in relation to these activities. It would also be useful to have a better understanding of the interacting effects of water availability, temperature, and herbivory so that the response of alpine plant communities to changes in any of these factors can be better understood and predicted. This would provide managers a basis for adaptive management of elk, recreation, and grazing in a manner that protects all communities in this complex ecosystem.

\section{ACKNOWLEDGMENTS}

We are grateful to the wildlife and resource managers of Great Sand Dunes National Park and Preserve, Rio Grande National Forest, Colorado Division of Wildlife, and Baca National Wildlife Refuge for access to the study sites and logistical support. R. Rivale of CDOW identified the primary areas of concern and provided valuable knowledge of the backcountry and recreational use of the area, as well as led field crews on data collection missions. F. Bunch of GSD NPP provided information on comparison sites within GSDNPP. J. Wondzell, M. Kling, Z. Wiebe, S. Neid, S. Ratering, J. Jaminet, K. Holland, S. Gray, T. Williams, and N. Noah assisted with field data collection. We appreciate the helpful review comments of G. Auble, U.S. Geological Survey, P. Bovin, NPS, Danielle Johnston, CDOW, and 2 anonymous reviewers on drafts of this manuscript.

\section{Literature Cited}

Adams, A.W. 1982. Migrations. Pages 301-321 in J.W. Thomas and D.E. Toweill, editors, Elk of North America: ecology and management. Stackpole, Harrisburg, PA.

ArCher, S., AND L.L. TiEszen. 1980. Patterns of vegetation and herbivory in arctic tundra: results from the Research on Arctic Tundra Environments (RATE) program. Arctic and Alpine Research 12:531-552.
BRAZDA, A.R. 1953. Elk migration patterns and some of the factors affecting movements in the Gallatin River drainage, Montana. Journal of Wildlife Management 17:9-23.

Canfield, R.H. 1941. Application of the line interception method in sampling range vegetation. Journal of Forestry 39:388-394.

Chapin, F.S., III. 1980. Patterns of vegetation and herbivory in arctic tundra: results from the Research on Arctic Tundra Environments (RATE) program. Arctic and Alpine Research 12:553-563.

Coe, P.K., B.K. Johnson, J.W. Kern, S.L. Findholt, J.G. KIE, AND M.J. WisDOM. 2001. Responses of elk and mule deer to cattle in summer [abstract]. Journal of Range Management 54:205.

Cole, E.K., M.D. Pope, And R.G. Anthony. 1997. Effects of road management on movement and survival of Roosevelt elk. Journal of Wildlife Management 61: 1115-1126.

Hebblewhite, M., and E.H. Merrill. 2009. Trade-offs between predation risk and forage differ between migrant strategies in a migratory ungulate. Ecology 90 : 3445-3454.

Hebblewhite, M., E.H. Merrill, and G. McDermid. 2008. A multi-scale test of the forage maturation hypothesis in a partially migratory ungulate population. Ecological Monographs 78:141-166.

Johnston, D.B., D.J. Cooper, And N.T. HobBs. 2007. Elk browsing increases aboveground growth of waterstressed willows by modifying plant architecture. Oecologia 154:467-478.

2008. Water tables constrain height recovery of willow on Yellowstone's Northern Range. Ecological Applications 18:80-92.

LYON, L.J. 1979. Habitat effectiveness for elk as influenced by roads and cover. Journal of Forestry 79:658-660.

Millspaugh, J.J. 1999. Behavioral and physiological responses of elk to human disturbance in the southern Black Hills, South Dakota. Doctoral dissertation, University of Washington, Seattle, WA.

Morgantini, L.E., AND R.J. Hudson. 1989. Nutritional significance of wapiti (Cervus elaphus) migrations to alpine ranges in Western Alberta, Canada. Arctic and Alpine Research 21:288-295.

Naylor, L.M., M.J. Wisdom, And R.G. Anthony. 2009. Behavioral responses of North American elk to recreational activity. Journal of Wildlife Management 73: 328-338.

Peinetti, H.R., M.A. Kalkhan, and M.B. Coughenour. 2002. Long-term changes in willow spatial distribution on the elk winter range of Rocky Mountain National Park (USA). Landscape Ecology 17:341-354.

Peinetti, H.R., R.S.C. Menezes, and M.B. Coughenour. 2001. Changes induced by elk browsing in the aboveground biomass production and distribution of willow (Salix monticola Bebb): their relationships with plant water, carbon, and nitrogen dynamics. Oecologia 127 : 334-342.

Ray, A.J., J.J. Barsugli, K.B. Averyt, K. Wolter, M. Hoerling, N. Doesken, B. Udall, and R.S. WebB. 2008. Climate change in Colorado: a synthesis to support water resources management and adaptation. CU-Boulder University Communications, Marketing and Creative Solutions, Boulder, CO. 52 pp.

RowLand, M.M., M.J. Wisdom, B.K. Johnson, and J.G. KIE. 2000. Elk distribution and modeling in relation to roads. Journal of Wildlife Management 64:672-68 
Schultz, R.D., AND J.A. BaILEy. 1974. Responses of national park elk to human activity. Journal of Wildlife Management 42:91-100.

Singer, FJ., L.C. MaCK, AND R.G. Cates. 1994. Ungulate herbivory of willows on Yellowstone's northern winter range. Journal of Range Management 47:435-443.

Stewart, K.M., R.T. Bowyer, J.G. Kie, N.J. Cimon, AND B.K. Johnson. 2002. Journal of Mammalogy 83: 229-244.

White, C.A., C.E. Olmsted, and C.E. Kay. 1998. Aspen, elk and fire in the Rocky Mountain national parks of North America. Wildlife Society Bulletin 26:449-462.

White, P.J., J.J. Borkowski, T. DaVIS, R.A. Garrott, D.P. Reinhart, and D.C. MCCluRe. 2009. Wildlife responses to park visitors in winter. Pages 581-602 [chapter 26] in R. Garrott, P.J. White, and F. Watson, editors, The ecology of large mammals in central Yellowstone: sixteen years of integrated field studies. Academic Press, San Diego, CA. 712 pp.

Zeigenfuss, L.C. 2006. Alpine plant community trends on the elk summer range of Rocky Mountain National Park, Colorado: an analysis of existing data. Open-File Report 2006-1122, U.S. Geological Survey, Fort Collins Science Center. 21 pp.

Zeigenfuss, L.C., F.J. Singer, S.A. Williams, and T.L. JoHNSON. 2002. Influences of herbivory and water on willow in elk winter range. Journal of Wildlife Management 66:788-795.

Received 10 December 2009 Accepted 21 September 2010 